\title{
Aspectos qualitativos da silagem de capim-elefante com fubá de milho e casca de soja
}

\section{Qualitative aspects of elephantgrass silage with corn meal and soybean hulls}

\author{
Alexandro Pereira Andrade ${ }^{1 *}$; Danilo Gusmão de Quadros²; \\ André Ricardo Gomes Bezerra ${ }^{3}$; José Augusto Reis Almeida ${ }^{3}$; \\ Paulo Henrique Santos Silva ${ }^{4}$; Jorge Aurélio Macedo Araújo ${ }^{3}$
}

\section{Resumo}

Objetivou-se com este trabalho, avaliar os efeitos do fubá de milho e da casca de soja na silagem de Pennisetum purpureum cv. Roxo Botucatu. Utilizou-se um delineamento inteiramente casualizado, em esquema de parcela subdividida, com sete tratamentos (capim-elefante puro, casca de soja (5 e 10\%) e fubá de milho ( 5 e 10\%) de forma isolada ou conjunta em mesmas proporções totalizando 5 e 10\%), três tempos de abertura e três repetições. Foram utilizados silos experimentais constituídos de baldes plásticos de 20 L com tampa. Os silos foram abertos aos 7, 14 e 28 dias após a ensilagem, sendo avaliadas as perdas por efluentes, matéria seca, $\mathrm{pH}$, acidez titulável e a estabilidade aeróbia da massa ensilada. A utilização de aditivos na ensilagem reduziu as perdas por efluentes. A matéria seca variou com a utilização de aditivos, obtendo valores mais elevados na silagem com $10 \%$ de casca de soja ou fubá de milho, em relação à silagem de capim-elefante puro. Os resultados de $\mathrm{pH}$ apresentaram interação entre os tratamentos e tempo de abertura, havendo valores desejados aos $7^{\circ}$ dia após a ensilagem. A quebra da estabilidade aeróbia ocorreu $48 \mathrm{~h}$ após a abertura do silo para os tratamentos contendo fubá de milho individual ou em conjunto com casca de soja para os dois níveis. A utilização de fubá de milho, seja individualmente ou em conjunto com a casca de soja, foi eficiente na melhoria do padrão fermentativo da silagem de capim elefante, entretanto, cuidados adicionais devem ser tomados quanto ao manejo pós-abertura do silo.

Palavras-chave: Efluentes, estabilidade aeróbia, forragem, $\mathrm{pH}$

\begin{abstract}
The objective of this study was to evaluate the effects of corn meal and soybean hulls in silage Pennisetum purpureum cv. Roxo Botucatu. The experiment has adopted a completely randomized design in a splitplot, with seven treatments (elephant grass pure soy cone (5 and 10\%) and corn meal (5 and 10\%) alone or in joint same proportions totaling 5 to $10 \%$ ), three open times and three replications. We used a randomized design in a split-plot, with seven treatments (elephant grass pure, soybean hulls (5 and $10 \%$ ) and corn meal (5 and 10\%) of isolated form or together in the same proportions totalizing 5 and $10 \%$, three open times and three replications. There were used experimental silos made of bucket of 20 L. Silos were opened at 7, 14 and 28 days after ensiling, and evaluated the effluent losses, dry matter,

\footnotetext{
${ }^{1}$ Doutorando em Zootecnia, UESB, Campus Itapetinga, Bahia. Bolsista FAPESB. E-mail: alexandro andrade@hotmail.com

2 Prof. da Faculdade de Agronomia, Universidade do Estado da Bahia, UNEB, Campus IX. NEPPA-Núcleo de Estudos e Pesquisas em Produção Animal, Barreiras, Bahia, BA. E-mail: uneb_neppa@yahoo.com.br

${ }^{3}$ Engenheiro(s) Agrônomo(s) da UNEB, Campus IX. Barreiras, Bahia, BA. E-mail: andrerickgbi@hotmail.com; gutoja21@ hotmail.com; jorge.aurelio@hotmail.com

${ }^{4}$ Discente de Agronomia, UNEB, Campus IX. Barreiras, Bahia, BA. E-mail: uneb_neppa@yahoo.com.br

*Autor para correspondência
} 
$\mathrm{pH}$, total titratable acidity (TTA) and aerobic stability of silage. The use of additives in ensiling reduced the effluent losses. Dry matter varied with the use of additives, obtaining higher values for the silage with $10 \%$ soybean hulls or corn meal, in relation to elephant grass pure silage. The results of $\mathrm{pH}$ present interaction between treatment and time of opening, with the desired values 7 days after ensiling. The breaking of aerobic stability occurred 48 hours after opening the silo for the treatments containing corn meal alone or together with soybean hulls for both levels. The use of corn meal, either individually or in combination with soybean hulls, was effective in improving the standard of silage fermentation elephant grass, however, additional care should be taken about management after opening the silo.

Key words: Effluents, aerobic stability, forage, $\mathrm{pH}$

\section{Introdução}

O capim-elefante (Pennisetum purpureum Shum.) é uma forrageira com excelente potencial de produção de matéria seca por área cultivada, com quantidades razoáveis de carboidratos solúveis. Apesar disso, o teor de umidade elevado, na fase em que é ótimo o seu valor nutritivo, representa um obstáculo para o seu aproveitamento na forma de silagem, pois resulta em fermentações indesejáveis, com consideráveis perdas de nutrientes (ZANINE et al., 2006).

Porém, da forma em que vêm sendo manejado este capim, têm levado a queda de valor nutricional devido à maturidade das plantas. Nesse contexto, a ensilagem é a alternativa mais viável para sua conservação. Por outro lado, as características inerentes à planta, como baixos teores de matéria seca (MS) e carboidratos solúveis, bem como alto poder tampão, limitam o uso dessa técnica. Para contornar essas limitações, vários aditivos têm sido adicionados ao capim no momento da ensilagem no intuito de melhorar o padrão fermentativo e, consequentemente, a qualidade da silagem (REZENDE et al., 2008). Na escolha dos aditivos, deve ser considerado a facilidade de manipulação, disponibilidade e o custo de aquisição.

Segundo Silva et al. (2007), os aditivos mais utilizados na ensilagem do capim-elefante são os materiais secos, que elevam o teor de MS e aumentam as chances de obter fermentação adequada. Entre esses materiais, esses autores citaram algumas fontes de carboidratos solúveis, como fubá de milho, farelo de trigo, polpa cítrica e resíduos regionais da agroindústria.
O fubá de milho e obtido da moagem seca da mistura de gérmen (com ou sem a remoção do óleo), tegumentos e de parte da porção amilácea da semente. Em composição química esse alimento assemelha-se ao farelo ou a quirera e praticamente tem o mesmo valor nutritivo (ANDRIGUETTO, 2002).

A casca da soja (Glycine max) é um subproduto do beneficiamento do grão de soja que apresenta custo relativamente baixo em locais próximos às empresas processadoras, como no caso da região de Barreiras, BA. A cada tonelada de soja que entra para ser processado, cerca de $2 \%$ é transformado em casca de soja, essa porcentagem pode variar de $0 \%$ a 3\%, de acordo com os objetivos de produção de farelo de soja (ANDRADE; QUADROS, 2011).

Sob os aspectos nutricionais, Restle et al. (2004) relataram que por apresentar elevado teor de FDN da casca de soja, foi inicialmente estudada como uma opção para substituição da fração volumoso da dieta de ruminantes. Entretanto, este subproduto apresenta elevada digestibilidade da FDN, proporcionando elevada produção de ácidos graxos voláteis no rúmen, em razão da excelente fermentabilidade da fibra no rúmen (BACH et al., 1999), além dos benefícios decorrentes da digestão da fibra da dieta total sobre o $\mathrm{pH}$ ruminal (LUDDEN; CECAVA; HENDRIX, 1995).

A medida do valor de $\mathrm{pH}$ em silagens foi considerada, no passado, como um importante indicador da qualidade de fermentação, sendo inclusive possível classificar as silagens em termos de qualidade. No entanto, atualmente essa variável deve ser usada com critério para fazer inferências 
à qualidade de fermentação (ANDRADE et al., 2010). Porém, segundo Cherney e Cherney (2003), o $\mathrm{pH}$ ainda permanece como um bom indicador da qualidade de fermentação em silagens com baixo teor de MS.

Segundo Pinho et al. (2008), a ensilagem de capim sem aditivos está sujeita a significativas perdas por efluente, o qual contém grandes quantidades de compostos orgânicos, tais como: açúcares, ácidos orgânicos e proteínas. Como formas de diminuição das perdas por effuente, pode-se utilizar técnicas, como o emurchecimento e aplicação de aditivos absorventes da umidade.

Outra importante etapa na utilização de silagens é o manejo de pós-abertura do silo, pois o ambiente anaeróbio, um dos responsáveis pela conservação da forragem, passa a ser aeróbio. Nessa ocasião, organismos que estavam em dormência na ausência de oxigênio multiplicam-se rapidamente, promovendo intensa atividade metabólica, gerando calor e consumindo nutrientes, elevando as perdas de MS e reduzindo o valor nutritivo do alimento (SIQUEIRA; BERNADES; REIS, 2005). As perdas após a abertura do silo dependem do manejo imposto ao silo, mas a extensão de deterioração do material está relacionada à estabilidade aeróbia da silagem (NUSSIO; PAZIANI; NUSSIO, 2002).

$\mathrm{Na}$ academia este assunto é denominado estabilidadeaeróbia da silagem é definido poralguns pesquisadores (RUPPEL et al., 1995; DRIEHUIS; OUDE ELFERINK; VAN WIKSELAAR, 2001) como sendo o tempo observado para que a massa de silagem, após a abertura do silo, apresente elevação na temperatura $\left(1\right.$ a $\left.3^{\circ} \mathrm{C}\right)$ em relação à temperatura ambiente.

Bernardes, Reis e Moreira (2005) observaram que a deterioração aeróbia em silagens de capins tropicais é caracterizada principalmente por bactérias aeróbias, em vez de fungos e leveduras, por estas apresentarem alto teor de umidade, reduzida acidez e baixa fonte de nutrientes disponíveis na massa ensilada. Além disso, silagens com estas características apresentam fermentações secundárias, o que impede a intensa atividade de microrganismos deterioradores (BERNARDES et al., 2007).

Objetivou-se com este trabalho, avaliar a cinética fermentativa, perdas por efluentes, e a estabilidade aeróbia da silagem de capim-elefante com a utilização da casquinha de soja e fubá de milho como aditivos secos e nutritivos.

\section{Material e Métodos}

O experimento foi conduzido no Laboratório do Núcleo de Estudos e Pesquisa em Produção Animal - NEPPA da Universidade do Estado da Bahia (UNEB), Campus IX, na cidade de BarreirasBA. O capim utilizado foi capim-elefante roxo (Pennisetum purpureum cv. Roxo Botucatu). $\mathrm{O}$ experimento utilizou-se de um delineamento inteiramente casualizado, em esquema de parcela subdividida, com 7 tratamentos (CE100 = capimelefante (testemunha); CS5 $=95 \%$ de capim-elefante $+5 \%$ de casquinha de soja; $\operatorname{CS} 10=90 \%$ de capimelefante $+10 \%$ de casquinha de soja; FM5 $=95 \%$ de capim-elefante $+5 \%$ de fubá de milho; FM10 $=90 \%$ de capim-elefante $+10 \%$ de fubá de milho; CSFM5 $=95 \%$ de capim-elefante $+2,5 \%$ de casquinha de soja $+2,5 \%$ de fubá de milho; e CSFM10 $=90 \%$ de capim-elefante $+5 \%$ de casquinha de soja $+5 \%$ de fubá de milho), 3 tempos de abertura (7, 14 e 28 dias pós-ensilagem) e 3 repetições, totalizando 63 unidades experimentais (silos).

O capim-elefante apresentou no momento do corte (80 dias de rebrota), 1,7 $\mathrm{m}$ de altura. Contudo, mesmo com essa idade de corte, o estádio vegetativo era imaturo, pois foi cultivado em área de baixa drenagem, apresentando 15\% de MS. As plantas foram cortadas na base com auxílio de uma roçadeira costal, e picado mecanicamente em partículas de 2 a $3 \mathrm{~cm}$ de tamanho, utilizando-se máquina forrageira estacionária. A casquinha de soja foi adquirida em casa comercial, bem como o fubá de milho. Após homogeneização entre o 
capim picado e os aditivos, a massa de forragem foi ensilada em silos experimentais.

Os silos experimentais foram constituídos de baldes com tampa, tendo capacidade de 20L, nos quais foi colocado $4 \mathrm{~kg}$ de areia e tecido de algodão para separação da areia e da forragem, com a intenção de captação de efluentes. $\mathrm{O}$ conjunto foi identificado e pesado para, em seguida, ensilar o material, conforme o tratamento, compactando através do pisoteio. Após o enchimento, os silos foram fechados, vedados com fita adesiva e pesados. A densidade média obtida foi de $520 \mathrm{~kg} / \mathrm{m}^{3}$.

Após 7, 14 e 28 dias pós-ensilagem, os silos foram novamente pesados, mensurando as perdas por efluentes. As perdas por efluente foram calculadas pela equação abaixo, baseadas na diferença de peso da areia e relacionadas com a massa de forragem fresca no fechamento.

$$
\mathrm{E}=[(\mathrm{PVf}-\mathrm{Tb})-(\mathrm{PVi}-\mathrm{Tb})] / \mathrm{MFi} \times 100,
$$

onde:

E: produção de efluentes ( $\mathrm{kg} /$ tonelada de silagem);

PVi: peso do balde vazio + peso da areia no fechamento $(\mathrm{kg})$;

PVf: peso do balde vazio + peso da areia na abertura (kg);

Tb: tara do balde;

MFi: massa de forragem no fechamento $(\mathrm{kg})$.

$\mathrm{Na}$ abertura dos silos, foram retiradas subamostras para determinação do teor de MS, em estufa com circulação forçada de ar a temperatura de $60^{\circ} \mathrm{C}( \pm 5)$ por 72 horas; determinação do $\mathrm{pH}$ e da acidez total titulável (ATT), utilizando-se das metodologias descritas por Silva e Queiroz (2002).
A avaliação da estabilidade aeróbia foi realizada somente na abertura dos silos aos 28 dias, sendo retirado aproximadamente $2 \mathrm{~kg}$ da silagem que foram transferidos para caixas de isopor de $5 \mathrm{~L}$, para avaliação. A temperatura da silagem foi medida nos tempos: 0, 6, 12, 24, 48, 72 e 96 h após a abertura, utilizando-se de termômetros de mercúrio inserido a $10 \mathrm{~cm}$ dentro da massa contida na caixa de isopor, medindo também a temperatura ambiental, cujos valores foram: $\mathrm{T}_{0}=28,2^{\circ} \mathrm{C} ; \mathrm{T}_{6}=25,0^{\circ} \mathrm{C} ; \mathrm{T}_{12}=26,5^{\circ}$; $\mathrm{T}_{24}=31,5 ; \mathrm{T}_{48}=31,0^{\circ} \mathrm{C} ; \mathrm{T}_{72}=28,5^{\circ} \mathrm{C}$ e $\mathrm{T}_{96}=32,0^{\circ} \mathrm{C}$.

Os dados foram tabulados e submetidos à análise de variância para verificação da significância dos tratamentos por meio do Teste F, ao nível de $5 \%$ de probabilidade. Para efeito significativo dos tratamentos, foi realizado desdobramento dos graus de liberdade em efeitos principais e da interação. As médias de $\mathrm{pH}$, ATT, MS e perdas por efluentes foram comparadas pelo teste de Tukey a $5 \%$ de probabilidade, enquanto a estabilidade aeróbia foi analisada por polinômios ortogonais. As análises estatísticas foram realizadas utilizando-se o programa GENES (CRUZ, 2006).

\section{Resultados e Discussão}

Não houve interação entre aditivos e período pós-ensilagem sobre as perdas por efluente e o percentual de MS (Tabela 1). A utilização de aditivos na ensilagem de capim-elefante diminuiu significativamente $(\mathrm{P}<0,05)$ as perdas por efluentes. A casca de soja e/ou o fubá de milho nas proporções testadas resultaram, em uma redução média de 58\% na quantidade perdida por $\mathrm{m}^{3}$, quando comparados à silagem de capim-elefante exclusivo. Esses resultados foram similares aos observados por Zanine et al. (2006), que verificaram efeito positivo da adição de farelo de trigo na redução das perdas por efluentes em silagens de capim-elefante. 
Tabela 1. Perdas por efluentes e teor de matéria seca (\%MS) na silagem de capim-elefante (CE) com proporções, na matéria natural, de casca de soja (CS) e fubá de milho (FM).

\begin{tabular}{ccc}
\hline Tratamentos & Perdas por efluentes $\left(\mathrm{kg} / \mathrm{m}^{3}\right)$ & MS (\%) \\
\hline CE100\% & $28,4 \mathrm{a}$ & $21,1 \mathrm{~b}$ \\
CS5\% & $11,0 \mathrm{~b}$ & $24,1 \mathrm{ab}$ \\
CS10\% & $2,6 \mathrm{~b}$ & $28,3 \mathrm{a}$ \\
FM5\% & $6,3 \mathrm{~b}$ & $23,8 \mathrm{ab}$ \\
FM10\% & $6,4 \mathrm{~b}$ & $28,9 \mathrm{a}$ \\
CSFM5\% & $11,8 \mathrm{~b}$ & $23,1 \mathrm{ab}$ \\
CSFM10\% & $6,8 \mathrm{~b}$ & $26,5 \mathrm{ab}$ \\
\hline C.V. (\%) & 11,4 & 6,43 \\
\hline 7 & Dias pós-ensilagem \\
\hline 14 & $9,4 \mathrm{ab}$ & $24,5 \mathrm{a}$ \\
28 & $9,2 \mathrm{~b}$ & $25,2 \mathrm{a}$ \\
\hline C.V. (\%) & $12,8 \mathrm{a}$ & $25,5 \mathrm{a}$ \\
\hline
\end{tabular}

Médias seguidas pelas mesmas letras na coluna não diferenciam estaticamente entre si (Tukey $<5 \%)$

Fonte: Elaboração dos autores.

É válido considerar que o efluente das silagens carreia compostos nitrogenados, açúcares, ácidos orgânicos e sais minerais (IGARASI, 2002), de maneira que a inclusão desse aditivos foi uma alternativa vantajosa, pois impediu o escape de nutrientes altamente digestíveis via efluentes, reduzindo as perdas de MS. Vários aditivos são utilizados como absorventes da umidade, como a casca de café, farelo de trigo e polpa cítrica, porém o fubá de milho e a casquinha de soja representam uma boa alternativa, por apresentar elevado valor nutritivo. Quanto ao período pós-ensilagem, as perdas por efluentes foram influenciada pelo tempo de ensilagem, com valores mais elevados após o $14^{\circ}$ dia (Tabela 1).

As perdas por efluente observadas neste trabalho foram superiores quando comparadas aos 13,0; 3,05; 2,25; $2,85 \mathrm{~kg} / \mathrm{m}^{3}$ observadas por Pinho et al. (2008), ao testarem $0,4,8$ e $12 \%$ de farelo de mandioca como aditivo na ensilagem de capim elefante, respectivamente, que apresentava no momento do corte $22 \%$ de MS.

O percentual de MS variou com a utilização de aditivos, obtendo valores mais altos na silagem com
$10 \%$ de casca de soja ou fubá de milho, em relação à testemunha (Tabela 1). Esses resultados corroboram com os apresentados por Quadros et al. (2003), ao acrescentar a casca de café; Zanine et al. (2006) com adição de farelo de trigo e Rezende et al. (2008) ao adicionar diversos aditivos secos e nutritivos, na ensilagem de capim elefante.

A silagem de capim elefante puro apresentou um incremento no teor de MS de $41 \%$, em relação ao capim natural, enquanto que, a adição de $10 \%$ de casca de soja e fubá de milho apresentou respectivamente 89 e $93 \%$ de acréscimo na MS após a silagem, ou seja, a utilização de $10 \%$ de casca de soja e fubá de milho aumentou na silagem 34 e 37\% de MS, em relação à silagem de capim elefante puro.

Os aditivos são citados na literatura como forma de aumentar o percentual de MS pela absorção do excesso de umidade (IGARASI, 2002; ZANINE et al., 2006) melhorando a fermentação microbiana e o valor nutricional em silagem de gramíneas.

$\mathrm{O} \mathrm{pH}$ da silagem foi afetado pela interação tratamento $\mathrm{x}$ tempo pós-ensilagem $(\mathrm{P}<0,05)$. De forma geral, houve redução do $\mathrm{pH}$ das silagens após o $7^{\circ}$ dia pós-ensilagem (Tabela 2 ). Nos processos 
biológicos envolvidos na transformação da forragem úmida em silagem, em meio anaeróbico, ocorre o crescimento de bactérias homofermentativas, as quais fermentam os carboidratos solúveis em água, transformando em ácido lático, que é eficiente na redução do pH (SEGLAR, 1997).

Tabela 2. Valores de $\mathrm{pH}$ da silagem de capim elefante (CE) com diferentes proporções de casquinha de soja (CS) e fubá de milho (FM) e tempo de abertura.

\begin{tabular}{lccc}
\hline \multirow{2}{*}{ Tratamentos } & \multicolumn{3}{c}{ Dias pós-ensilagem } \\
\cline { 2 - 4 } & 7 & 14 & 28 \\
\hline CE100\% & $3,81 \mathrm{cA}$ & $3,92 \mathrm{bcA}$ & $3,50 \mathrm{cB}$ \\
CS5\% & $4,14 \mathrm{abA}$ & $4,07 \mathrm{bA}$ & $3,86 \mathrm{bB}$ \\
$\mathrm{CS} 10 \%$ & $4,32 \mathrm{aAB}$ & $4,48 \mathrm{aA}$ & $4,30 \mathrm{aB}$ \\
FM5\% & $3,96 \mathrm{bcA}$ & $3,98 \mathrm{bcA}$ & $3,67 \mathrm{bcB}$ \\
FM10\% & $3,87 \mathrm{cA}$ & $3,80 \mathrm{cA}$ & $3,49 \mathrm{cB}$ \\
CSFM5\% & $3,83 \mathrm{cA}$ & $3,87 \mathrm{bcA}$ & $3,45 \mathrm{cB}$ \\
CSFM10\% & $3,95 \mathrm{bcA}$ & $4,02 \mathrm{bcA}$ & $3,64 \mathrm{bcB}$ \\
\hline \multicolumn{1}{c}{ C.V. (tratamentos) $=4,21$} & C.V. (Tempo de abertura) $=3,26$ &
\end{tabular}

As médias seguidas de uma mesma letra, maiúsculas entre linhas e minúsculas entre coluna, não diferem estatisticamente entre si pelo Teste de Tukey ao nível de 5\% de probabilidade.

Fonte: Elaboração dos autores.

A adição do fubá de milho ao capim-elefante no momento da ensilagem, seja sozinho, ou associado com a casca de soja, resultou em silagens com valores mais baixos de $\mathrm{pH}$, em comparação com a silagem aditivada apenas com a casca de soja (Tabela 2). Segundo Van Soest (1994), em silagens convencionalmente conservadas, valores de $\mathrm{pH}$ elevados são indicativos de maior produção dos ácidos butírico e acético, resultado de fermentações indesejáveis.

Se uma silagem estável de baixo pH não é obtida, o desenvolvimento de clostrídios é estimulado e a fermentação secundária ocorrerá, sendo indesejável, sua participação no processo, pois este age contra a preservação destruindo o ácido lático, aumentando o $\mathrm{pH}$, diminuindo o valor nutritivo pelo catabolismo de aminoácidos, produção de diversas substâncias voláteis antipalatáveis, principalmente o ácido butírico (MCDONALD; HENDERSON; HERON, 1991). Segundo estes autores, os resultados deste trabalho estão dentro da faixa considerada ideal, que é de, aproximadamente 3,5 a 4,2, com exceção da utilização de $10 \%$ de casca de soja. Zanine et al. (2006) observaram redução do $\mathrm{pH}$ de silagens de capim-elefante com $15 \%$ farelo de trigo.

A Acidez Titulável Total (ATT) não sofreu interação tratamento $\mathrm{x}$ tempo pós-ensilagem, nem efeito do tempo pós-ensilagem $(\mathrm{P}>0,05)$. Por outro lado, o uso de $10 \%$ de fubá de milho ou sua mistura com a casquinha de soja, totalizando 5 ou $10 \%$ do capim-elefante, resultou em valores mais elevados de ATT (Figura 1). A aferição da ATT mostrou-se indicativo sensível que, juntamente com o $\mathrm{pH}$, deve ser utilizado na avaliação da cinética fermentativa de silagens. 
Figura 1. Valores da Acidez Total Titulável (ATT) das silagens de capim-elefante (CE) com diferentes proporções de casquinha de soja (CS) e fubá de milho (FM).

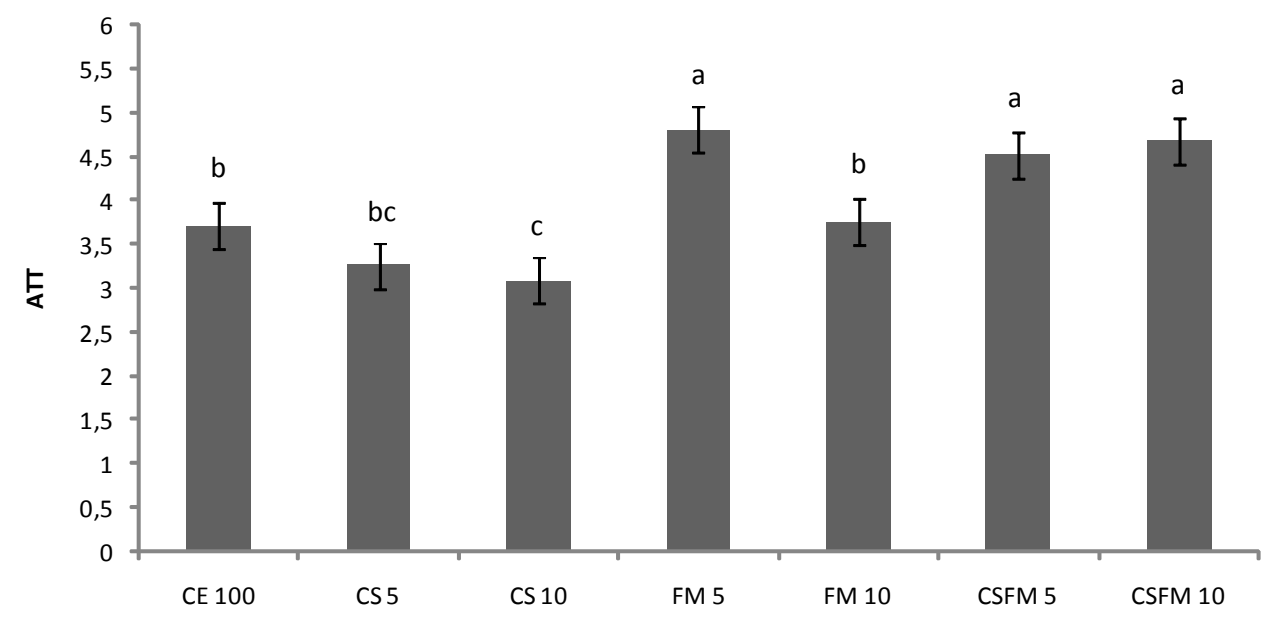

Médias seguidas pelas mesmas letras não diferenciam estaticamente entre si (Tukey $<5 \%$ )

Fonte: Elaboração dos autores.

A utilização de aditivos influenciou na estabilidade aeróbia da silagem de capim elefante $(\mathrm{P}<0,05)$. Com o passar do tempo cronológico no tempo de abertura do silo, a alteração da temperatura da silagem ajustou-se a equações quadráticas em todos os tratamentos, observando-se elevados coeficientes de determinação (Figura 2).

Houve a quebra da estabilidade aeróbia 48h após a abertura do silo para os tratamentos contendo fubá de milho individual ou em conjunto com casca de soja para os dois níveis, sendo indicado pelo aumento da temperatura da silagem acima de $3^{\circ} \mathrm{C}$, em relação à temperatura ambiente (DRIEHUIS; OUDE ELFERINK; VAN WIKSELAAR, 2001), provavelmente este aumento de temperatura ocorreu pela ação de microrganismos oportunista que iniciaram suas atividades metabólicas produzindo calor e consumindo carboidratos solúveis residuais, podendo acarretar em perdas de matéria seca e energia.

Após 12 horas pós-abertura, as temperaturas das silagens subiram acentuadamente (Figura 2), comportamentos semelhantes aos observado por Amaral et al. (2008) estudando silagens de capim-marandu com diferentes densidades de compactação.

A utilização de fubá de milho individualmente ou em conjunto com casca de soja nas doses de 5 e $10 \%$ apresentou padrões semelhantes de aumento de temperaturas, com grande instabilidade da silagem, principalmente nas primeiras 12 horas, tendo seus pontos de máxima de 36; 38; 37 e 37 ${ }^{\circ} \mathrm{C}$, respectivamente para os tratamentos de FM 5; FM 10; CSFM 5 e CSFM 10, sendo estes valores inferiores aos do capim-elefante puro que ficou com o ponto de máxima de $33^{\circ} \mathrm{C}$ após a abertura.

As temperaturas alcançadas neste trabalho foram superiores às observadas por Bernardes et al. (2008), avaliando aditivos bacterianos e químicos em silagens de capim-marandu, as quais não ultrapassaram $27{ }^{\circ} \mathrm{C}$. Possivelmente, os ácidos orgânicos das silagens foram consumidos pelos microrganismos aeróbios, pois segundo Kung Junior (2001) estes microrganismos degradam o ácido lático com facilidade após a quebra da vedação gerando dióxido de carbono, etanol e ácido acético. 
Figura 2. Estabilidade aeróbia da silagem de capim elefante com aditivos secos e nutritivos. Capim-elefante puro (a); capim-elefante com casca de soja (b,c); capim-elefante com fubá de milho (d,e); capim-elefante com casca de soja e fubá de milho (f,g).
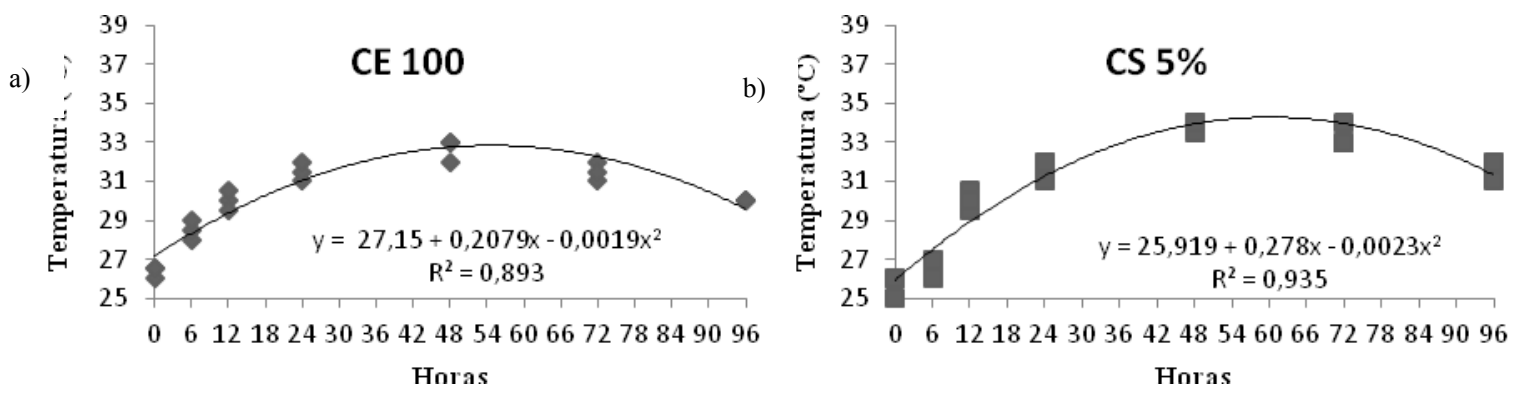

c)

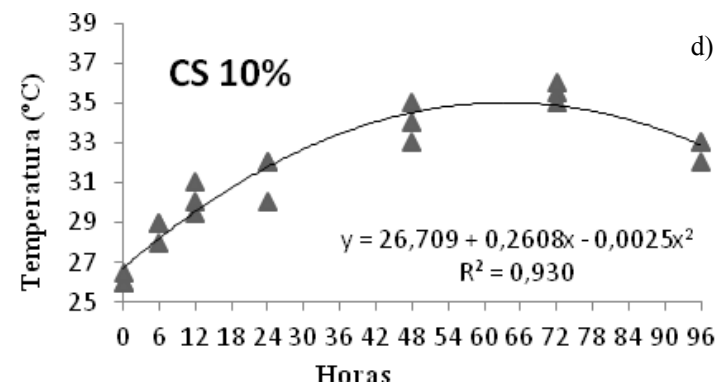

e)

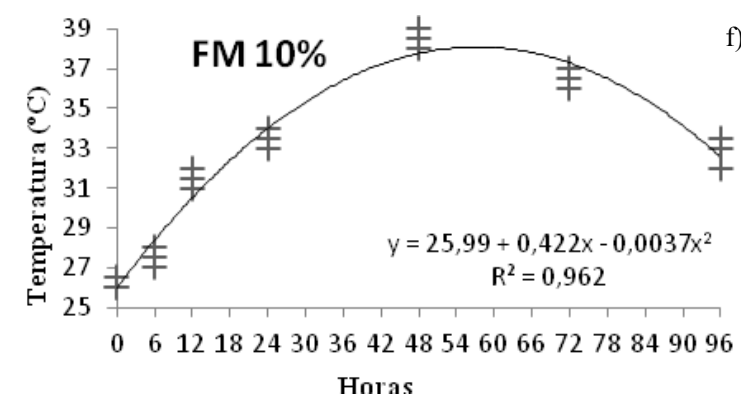

d)

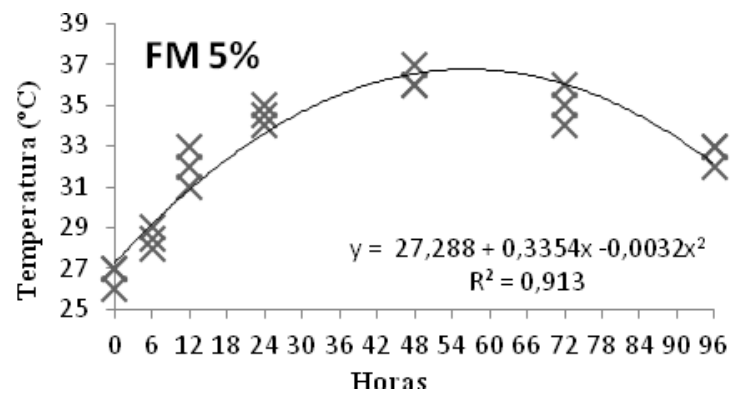

g)

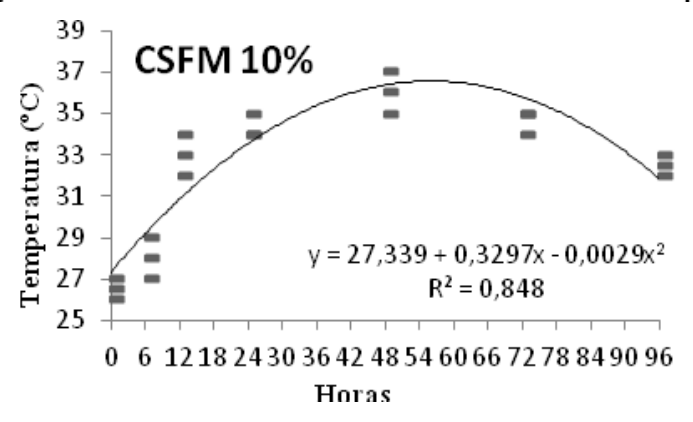

Fonte: Elaboração dos autores.

Silagens de capins tropicais apresentam deterioração caracterizada, principalmente por bactérias aeróbias, devido as suas particularidades como, alta umidade, estabilidade de fermentação em $\mathrm{pH}$ acima de 4,5 e ausência de substrato para o crescimento de microrganismos. O inverso ocorre com silagens de alta qualidade como as de milho e de sorgo, que são deterioradas principalmente por leveduras e fungos (BERNARDES et al., 2008).

No manejo pós-abertura do silo, tem-se a utilização e consumo de carboidratos solúveis, compostos nitrogenados e vitaminas que não foram degradados durante o processo de fermentação, 
em função do crescimento de microrganismos indesejáveis, resultando na diminuição do valor nutritivo (BERNARDES; REIS; AMARAL, 2009). Segundo Castro et al. (2006), as silagens que apresentam maior susceptibilidade à deterioração aeróbia foram àquelas ricas em carboidratos solúveis e amido, como as de milho, ou aquelas em que a fermentação foi restringida pelo uso de aditivos e/ou pelo emurchecimento excessivo da forragem antes da ensilagem.

$\mathrm{O}$ uso de aditivos nutritivos na ensilagem de capim é importante para melhorar a qualidade dos processos fermentativos, contudo, nesses casos, cuidados adicionais devem ser tomados quanto ao manejo pós-abertura do silo.

\section{Conclusões}

A utilização de fubá de milho, seja individualmente ou em conjunto com a casca de soja, foi boa alternativa para aumentar o teor de matéria seca, reduzir as perdas por efluentes e melhorar o padrão fermentativo da silagem de capim elefante. Entretanto, cuidados adicionais quanto ao manejo pós-abertura do silo. A utilização da silagem com adição de fubá de milho de casca de soja deverá ocorrer em até 48 horas, para evitar alterações no padrão de deterioração aeróbia desta silagem.

\section{Referências}

AMARAL, R. C.; BERNARDES, T. F.; SIQUEIRA, G. R.; REIS, R. A. Estabilidade aeróbia de silagens do capim-marandu submetidas a diferentes intensidades de compactação na ensilagem. Revista Brasileira de Zootecnia, Viçosa, MG, v. 37, n. 6, p. 977-983, 2008.

ANDRADE, A. P.; QUADROS, D. G. Composição bromatológica da casca de soja amonizada com uréia. Revista de Biologia e Ciências da Terra, João Pessoa, v. 11, n. 1, p. 38-46, 2011.

ANDRADE, A. P.; QUADROS, D. G.; SILVA, P. H. S.; ARAÚJO, J. A. M.; ALMEIDA, J. A. R.; SANTOS, L. I. J. Estabilidade aeróbia da silagem de capim elefante com diferentes proporções de casquinha de soja de fubá de milho. In: REUNIÃO ANUAL DA SOCIEDADE BRASILEIRA DE ZOOTECNIA, 47., 2010, Salvador. Anais... Salvador: SBZ, 2010, CD-ROM.

ANDRIGUETTO, J. M. Nutrição animal. In: ANDRIGUETTO, J. M.; PERLY, L.; MINARDI, I.; GEMAEL, A.; FLEMMING, J. S.; SOUZA, G. A.; BONA-FILHO, A. As bases e os fundamentos da nutrição animal. Os alimentos. São Paulo: Nobel, v. 1, 2002. p. 269-366.

BACH, A.; YOON, I. K.; STERN, M. D.; JUNG, H.G.; CHESTER-JONES, H. Effects of type of carbohydrate supplementation to lush pasture on microbial fermentation in continuous culture. Journal of Dairy Science, Savoy, v. 82, n. 1, p. 153-160, 1999.

BERNARDES, T. F.; REIS, R. A.; AMARAL, R. C. Chemical and microbiological changes and aerobic stability of Marandu grass silages after silo opening. Revista Brasileira de Zootecnia, Viçosa, MG, v. 38, n. 1, p. 1-8, 2009.

BERNARDES, T. F.; REIS, R. A.; AMARAL, R. C.; SIQUEIRA, G. R.; ROTH, A. P. T. P.; ROTH., M. T. P.; BERCHIELLI, T. T. Perfil fermentativo, estabilidade aeróbia e valor nutritivo de silagens de capim-marandu ensilado com aditivos. Revista Brasileira de Zootecnia, Viçosa, MG, v. 37, n. 10, p. 1728-1736, 2008.

BERNARDES, T. F.; REIS, R. A.; MOREIRA, A. L. Fermentative and microbiological profile of Marandugrass ensiled with citrus pulp pellets. Scientia Agricola, Piracicaba, v. 62, n. 3, p. 214-220, 2005.

BERNARDES, T. F.; REIS, R. A.; SIQUEIRA, G. R.; AMARAL, R. C.; PIRES, A. J. V. Estabilidade aeróbia da ração total e de silagens de capim-Marandu tratadas com aditivos químicos e bacterianos. Revista Brasileira de Zootecnia, Viçosa, MG, v. 36, n. 4, p. 754-762, 2007.

CASTRO, F. G. F.; NUSSIO, L. G.; HADDAD, C. M.; CAMPOS, F. P.; COELHO, R. M.; MARI, L. J.; TOLEDO, P. A. Perfil microbiológico, parâmetros físicos e estabilidade aeróbia de silagens de capimtifton 85 (Cynodon sp.) confeccionadas com distintas concentrações de matéria seca e aplicação de aditivos. Revista Brasileira de Zootecnia, Viçosa, MG, v. 35, n. 2, p. 358-371, 2006.

CHERNEY, J. H.; CHERNEY, D. J. R. Assessing silage quality. In: BUXTON, D. R.; MUCK, R. E.; HARRISON, J. H. Silage science and technology. Madison USA: American Society of Agronomy, Wisconsin, 2003. p. 141-198.

CRUZ, C. D. Programa genes: estatística experimental e matrizes. Viçosa, MG: UFV, 2006. 
DRIEHUIS, F.; OUDE ELFERINK, W. H.; VAN WIKSELAAR, P. G. Fermentation characteristics and aerobic stability of grass silage inoculant with Lactobacillus buchneri, with or without mofermentative lactic acid bacteria. Grass and Forage Science, Oxford, v. 56, n. 4, p. 330-343, 2001.

IGARASI, M. S. Controle de perdas na ensilagem de capim Tanzânia (Panicum maximum Jacq. cv. Tanzânia) sob os efeitos do teor de matéria seca, do tamanho de partícula, da estação do ano e da presença de inoculante bacteriano. 2002. Dissertação (Mestrado em Agronomia - Ciência Animal de Pastagens) - Escola Superior de Agricultura Luiz de Queiroz, Universidade de São Paulo, Piracicaba.

KUNG JUNIOR, L. Aditivos microbianos e químicos para silagem: efeitos na fermentação e resposta animal. In: WORKSHOP SOBRE MILHO PARA SILAGEM, 2., 2001. Piracicaba. Anais... Piracicaba: FEALQ, 2001. p. 53-74.

LUDDEN, P. A.; CECAVA, M. J.; HENDRIX, K. S. The value of soybean hulls as a replacement for corn in beef cattle diets formulated with or without added fat. Journal of Animal Science, Champaign, v. 73, n. 9, p. 2706-2711, 1995.

McDONALD, P.; HENDERSON, A. R.; HERON, S. J. E. The biochemistry of silage. 2. ed. Marlow: Chalcomb Publisher, 1991. 340 p.

NUSSIO, L. G.; PAZIANI, S. F.; NUSSIO, C. M. B. Ensilagem de capins tropicais. In.: REUNIÃO ANUAL DA SOCIEDADE BRASILEIRA DE ZOOTECNIA, 39., 2002. Recife. Anais ... Recife: SBZ, 2002. p. 60-99.

PINHO, B. D.; PIRES, A. J. V.; RIBEIRO, L. S. O.; CARVALHO, G. G. P. Ensilagem de capim-elefante com farelo de mandioca. Revista Brasileira de Saúde e Produção Animal, Salvador, v. 9, n. 4, p. 641-645, 2008.

QUADROS, D. G.; FIGUEIREDO, M. P.; NUSSIO, L. G.; SANTOS, N. C.; FEITOSA, J. V.; FERREIRA, J. Q. Fermentative and nutritional traits of elephantgrass silage added with increasing proportions of coffee hulls. Acta Scientiarum, Maringá, v. 25, n. 1, p. 207-214, 2003.
RESTLE, J.; FATURI, C.; FILHO, D. C.A.; BRONDANI, I. L.; SILVA, J. H. S.; KUSS, F.; SANTOS, C. V. M.; FERREIRA, J. J. Substituição do grão de sorgo por casca de soja na dieta de novilhos terminados em confinamento. Revista Brasileira de Zootecnia, Viçosa, MG, v. 33, n. 4, p. 1009-1015, 2004.

REZENDE, A. V.; GASTADELLO JÚNIOR, A. L.; VALERIANO, A. R.; CASALI, A. O.; MEDEIROS, L. T.; RODRIGUES, R. Uso de diferentes aditivos em silagem de capim-elefante. Ciência Agrotécnica, Lavras, v. 32, n. 1, p. 281-287, 2008.

RUPPEL, K. A.; PITT, R. E.; CHASE, L. E.; GALTON, D. M. Bunker silo management and its relationship to forage preservation on dairy farms. Journal of Dairy Science, Savoy, v. 78, n. 1, p. 141-153, 1995.

SEGLAR, B. Case studies that implicate silage mycotoxins as the cause of dairy herd problems. In: Silage: field to feedbunk. NRAES-99, Northeast Regional Agricultural Engineering Service, Ithaca, NY., 1997. p. 242-254.

SILVA, D. J.; QUEIROZ, A. C. Análise de alimentos: métodos químicos e biológicos. 3. ed. Viçosa: UFV, 2002.

SILVA, F. F.; AGUIAR, M. S. M. A.; VELOSO, C. M.; PIRES, A. J. V.; BONOMO, P.; DUTRA, G. S.; ALMEIDA, V. S.; CARVALHO, G. G. P.; SILVA, R. R.; DIAS, A. M.; ÍTAVO, L. C. V. Bagaço de mandioca na ensilagem do capim-elefante: qualidade das silagens e digestibilidade dos nutrientes. Arquivo Brasileiro de Medicina Veterinária e Zootecnia, Belo Horizonte, v. 59, n. 3, p. 719-729, 2007.

SIQUEIRA, G. R.; BERNARDES, T. F.; REIS, R. A. Instabilidade aeróbia de silagens: efeitos e possibilidades de prevenção. In: SIMPÓSIO SOBRE VOLUMOSOS NA PRODUÇÃO DE RUMINANTES, 2., 2005, Jaboticabal. Anais... Jaboticabal: FUNEP, 2005. p. 25-60.

VAN SOEST, P. J. Nutritional ecology of the ruminant. 2. ed. Ithaca: Cornell University, 1994. 476 p.

ZANINE, A. M.; SANTOS, E. M.; FERREIRA, D. J., OLIVEIRA, J. S.; ALMEIDA, J. C. C., PEREIRA, O. G. Avaliação da silagem de capim-elefante com adição de farelo de trigo. Archivos de Zootecnia, Córdoba, v. 55, n. 209, p. 75-84, 2006. 